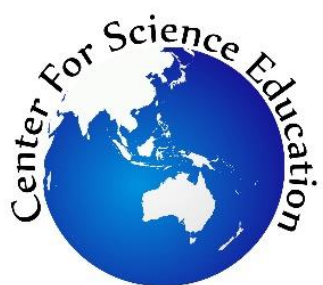

Tersedia online di EDUSAINS

Website: http://journal.uinjkt.ac.id/index.php/edusains

EDUSAINS, 12(2), 2020, 276-282

Research Artikel

\title{
THE EFFECT INQUIRY LEARNING MODEL WITH PICTORIAL RIDDLE TECHNIQUE DIGITAL BASED ON STUDENTS CREATIVE THINGKING ABILITY TOWARDS TEMPERATURE AND HEAT CONCEPT
}

\section{MODEL PEMBELAJARAN EFEK INQUIRY DENGAN TEKNIK PICTORIAL RIDDLE BERBASIS KEMAMPUAN HAL KREATIF MAHASISWA TERHADAP KONSEP SUHU DAN PANAS}

Dini Nurfitria*, Erina Hertanti

UIN Syarif Hidayatullah Jakarta, Indonesia

*dini.fitria14@mhs.uinjkt.ac.id

\begin{abstract}
This study to determine the effect of inquiry model with technique pictorial riddle based digital on students' creative thinking in temperature and heat concept. The study was conducted at SMAN 01 Rumpin on even semester year 2019/2020. Purposive sampling was used to determine the sample that class XI science I as experiment class and class XI science II as control class. This study used a quasi-experimental method as a research methodology and nonequivalent control group research design. This study used 8 essay questions as instrumental tests and questionnaires as instrumental nontest. Based on hypothesis test of posttest score by using $t$ ' test showed Sig. (2-tailed) < significant standard. This shows that learning using inquiry model with technique pictorial riddle based digital effect to the creative thinking of the student. Also, in the experimental $N$-Gain test the experimental class increased which was superior to the control class. While, the results of questionnaire response of students to learning using inquiry model with technique pictorial riddle base digital, who got a very good category (78\%).
\end{abstract}

Keywords: creative thinking ability; interactive; inquiry learning model; technique pictorial riddle; temperature and heat

\section{Abstrak}

Penelitian ini bertujuan untuk mengetahui pengaruh model inkuiri dengan teknik teka-teki bergambar berbasis digital terhadap kemampuan berpikir kreatif siswa dalam konsep suhu dan kalor. Penelitian dilaksanakan di SMAN 01 Rumpin pada semester genap tahun 2019/2020. Purposive sampling digunakan untuk menentukan sampel yaitu kelas XI IPA I sebagai kelas eksperimen dan kelas XI IPA II sebagai kelas kontrol. Penelitian ini menggunakan metode eksperimen semu sebagai metodologi penelitian dan desain penelitian kelompok kontrol nonequivalent. Penelitian ini menggunakan 8 soal essay sebagai tes instrumental dan angket sebagai instrumental nontest. Berdasarkan uji hipotesis skor posttest dengan menggunakan uji t menunjukkan Sig. (2tailed) <standar signifikan. Hal ini menunjukkan bahwa pembelajaran menggunakan model inkuiri dengan teknik bergambar teka-teki berbasis digital berpengaruh terhadap daya pikir kreatif siswa. Selain itu, pada uji coba N-Gain kelas eksperimen mengalami peningkatan yang lebih unggul dari kelas kontrol. Sedangkan hasil angket respon siswa terhadap pembelajaran menggunakan model inkuiri dengan teknik bergambar riddle base digital memperoleh kategori sangat baik (78\%)..

Kata Kunci: kemampuan berpikir kreatif; interaktif; model pembelajaran inkuiri; teka-teki gambar teknik; suhu dan panas

Permalink/DOI: http:// doi.org/10.15408/es.v12i2.18131

\section{INTRODUCTION}


Physics is a science related to natural phenomena (Wardani et al., 2019). Natural phenomena related to Physics concepts usually appear in real life (Nurrahmah, 2015). One of those Physics concepts is temperature and heat (Lestari et al., 2016). This concept is abstract, high analysis, and to be learnt needs creative thinking ability (Ma'rifah, 2016).

Creative thinking ability is defined as an ability that involves directed activities to find ideas or answers to solve problem (Tendrita et al., 2016). Guilford (1960) Said student, who has this ability can see the posibility of a creative answer of a problem from some point of views. The development of this ability needs special attentions from school. In fact, the implementation of creative thinking ability has not been maximal (Saputro et al., 2017). It is caused by first, schools still use Teacher Centered Learning (TCL) so that the students are being passive. Second, students are only given manipulated mathematic such as written questions without understanding the concept (Muliyani et al., 2014). Third, sometimes teachers do not involve students in an investigation when solving problems (Yuliani, 2017). Therefore, some solutions are needed in order to maximaze students' creative thinking ability in learning process. In this study, the implemented solutions are oriented in active learning, concept development, and investigation of a problem. One of learning processes which has those characteristics is inquiry learning model.

Inquiry learning model is a process that presents sistematical learning which involves students' activeness to investigate and look for solutions of a problem (Muhammad Fathurrohman, 2016). According to (Khoiri et al., 2019), inquiry learning model is effective in enhancing students' active thinking ability. However, the implementation of this model still has some obstacles. The obstacles are in early learning process do not interest students and in describing a problem still uses an analogue picture (Sund \& Trowbridge, 1967). Therefore, it is needed a technique that can interest students so that be able to enhance students' creative thinking ability in solving problem. Technique will be used in this study is pictorial riddle technique digital-based.

Pictorial riddle technique digital-based is a technique that presents a problem in the form of riddle for students to solve individual or group digital-based. (Kristianingsih et al., 2010). According to Nilova (2017) inquiry learning model with pictorial riddle technique is enhancing students' curiosity and be able to enhance students' creative thinking ability in solving problem.

The research was conducted with the aim of finding out how to improve student's creative thinking ability after the application of the inquiry learning model with pictorial riddle technique digital-based towards temperature and heat concept. The previous research the concerned about the inquiry learning model with pictorial riddle technique that have been carried out by Nurul Hidayah, etc focused on developing learning tools which are implemented in form of pictorial riddle puzzles that are displayed in worksheets and the form of the information manually. However, in this study, the inquiry learning model with pictorial riddle technique are presented digital-based, therefore it's expected to be capable for inviting the students to enhancing their creative thingking ability such as how to creating something, expending the way they think, and finding the various solutions to all the problem.

Based on the introduction, the writer intends to propose this research with the title: "The Effect Inquiry Learning Model with Pictorial Riddle Technique Digital based on Students. Creative Thingking Ability towards Temperature and Heat Concept".

\section{METHOD}

This study was conducted in SMAN 01 Rumpin in academic year 2019/2020. The study used quasi-experimental method with nonequivalent controlled group design ((Sugiyono, 2015); M. E. Winarno, 2013). The population was the whole students of SMAN 01 Rumpin. The sample consisted of XI IPA I as experimental class and XI IPA II as controlled class. This study used test and nontest instrument. Instrument of creative 
thinking ability test was given in pre-test and posttest. Test instrument contained eight essays that matched indicators of creative thinking ability by Torrance (1965), they are fluency, flexibility, originality, and elaboration. Meanwhile, the nontest was a quessionaire in order to know students' interest towards the implementation of inquiry learning model with pictorial riddle technique digital-based. The data were analized by using SPSS 22 (normality test, homogenity test, and analysis test).

\section{RESULTS AND DISCUSSION}

The recapitulation result of pre-test and posttest as shown in Table 1. Based on Table 1, it shows that both experimental class and controlled class experience an increase after being given different treatment.

Table 1. Recapitulation result of pre-test and post-test of experimental and controlled class

\begin{tabular}{lllll}
\hline Data & Pretest & & Posttest \\
\cline { 2 - 5 } & $\begin{array}{l}\text { Control } \\
\text { led } \\
\text { Class }\end{array}$ & $\begin{array}{l}\text { Experime } \\
\text { ntal } \\
\text { Class }\end{array}$ & $\begin{array}{l}\text { Control } \\
\text { led } \\
\text { Class }\end{array}$ & $\begin{array}{l}\text { Experime } \\
\text { ntal Class }\end{array}$ \\
\hline $\begin{array}{l}\text { The } \\
\text { lowest } \\
\text { score }\end{array}$ & 18,00 & 12,00 & 41,00 & 50,00 \\
\hline $\begin{array}{l}\text { The } \\
\text { highest } \\
\text { score }\end{array}$ & 59,00 & 53,00 & 76,00 & 82,00 \\
\hline $\begin{array}{l}\text { Mean } \\
\text { Modus }\end{array}$ & 35,73 & 29,77 & 54,67 & 66,73 \\
\hline $\begin{array}{l}\text { Media } \\
\text { n }\end{array}$ & 38,00 & 21,00 & 50,00 & 68,00 \\
\hline $\begin{array}{l}\text { Standa } \\
\text { rd of } \\
\text { Deviati } \\
\text { on }\end{array}$ & 11,36 & 11,10 & 9,36 & 8,99 \\
\hline
\end{tabular}

Furthermore, the percentage of each indicator of creative thinking ability can be seen in following picture 1 .

Based on Picture 1 shows that the percentage on students' creative thinking ability for each indicator either experimental or controlled class experiences an increase. The highest increase in experimental class is in flexibility indicator (42\%), while in controlled class is in originality indicator (19\%). However, the lowest increase in experimental class occurs in originality indicator (29\%), while in controlled class occurs in elaboration indicator (13\%). In fact, all of indicators experience more increase in experimental class than in controlled class. The result of normality test of pre-test and post-test as shown in following Table 2 . The result of homogenity test as shown in following Table 3.

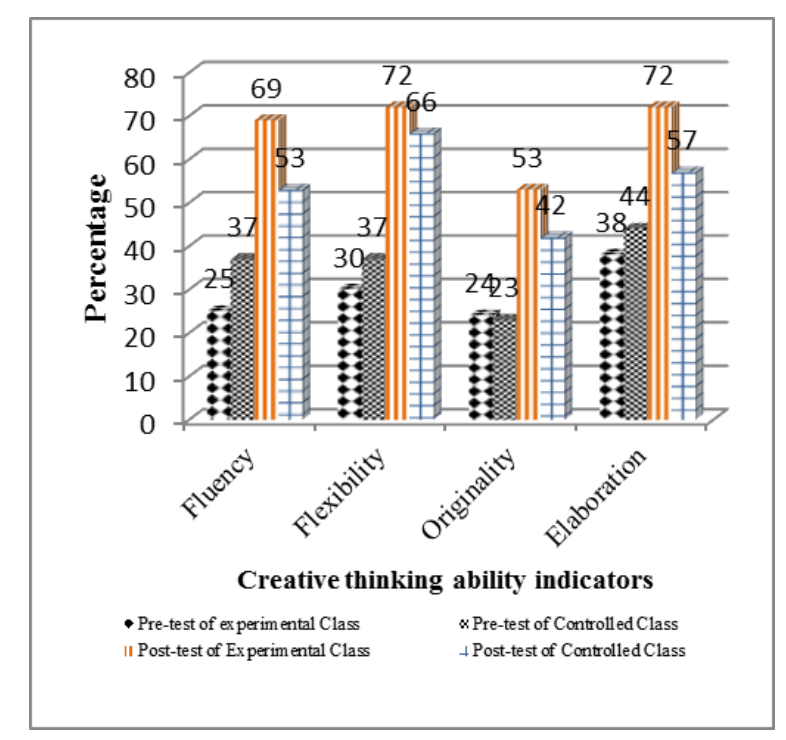

Picture 1. Diagram Of Pre-Test And Post-Test Result Of Students' Creative Thinking Ability Of Experimental And Controlled Class

Table 2. Result of normality test of pre-test and posttest of experimental and controlled class

\begin{tabular}{|c|c|c|c|c|}
\hline \multirow[t]{2}{*}{ Statistic } & \multicolumn{2}{|l|}{ Pretest } & \multicolumn{2}{|l|}{ Posttest } \\
\hline & $\begin{array}{l}\text { Eksperim } \\
\text { ental } \\
\text { Class }\end{array}$ & $\begin{array}{l}\text { Contro } \\
\text { lled } \\
\text { Class }\end{array}$ & $\begin{array}{l}\text { Experim } \\
\text { ental } \\
\text { Class }\end{array}$ & $\begin{array}{l}\text { Control } \\
\text { led } \\
\text { Class }\end{array}$ \\
\hline Df & 30 & 30 & 30 & 30 \\
\hline $\begin{array}{l}\text { Sig. (2- } \\
\text { tailed) }\end{array}$ & 0,022 & 0,122 & 0,390 & 0,019 \\
\hline $\begin{array}{l}\text { Taraf } \\
\text { Signific } \\
\text { ance } \\
\text { level } \\
(\alpha)\end{array}$ & 0,05 & & 0,05 & \\
\hline $\begin{array}{l}\text { Conclus } \\
\text { ion }\end{array}$ & $\begin{array}{l}\text { Abnorma } \\
\text { lyy } \\
\text { distribute } \\
\text { d data }\end{array}$ & $\begin{array}{l}\text { Norma } \\
\text { lly } \\
\text { distrib } \\
\text { uted } \\
\text { data }\end{array}$ & $\begin{array}{l}\text { Normall } \\
\text { y } \\
\text { distribut } \\
\text { ed data }\end{array}$ & $\begin{array}{l}\text { Abnor } \\
\text { mally } \\
\text { distribu } \\
\text { ted data }\end{array}$ \\
\hline
\end{tabular}


Table 3. Result of homogenity test of pre-test and posttest of experimental and controlled class

\begin{tabular}{|c|c|c|}
\hline Statistic & $\begin{array}{l}\text { Pre-test of } \\
\text { experimenta; }\end{array}$ & $\begin{array}{l}\text { Post-test } \\
\text { experimental }\end{array} \quad$ of \\
\hline & $\begin{array}{l}\text { and controlled } \\
\text { class }\end{array}$ & $\begin{array}{l}\text { and controlled } \\
\text { class }\end{array}$ \\
\hline Levene Satistic & 0,011 & 0,146 \\
\hline Sig. (2-tailed) & 0,918 & 0,704 \\
\hline $\begin{array}{l}\text { Significance } \\
\text { level }(\alpha)\end{array}$ & 0,05 & \\
\hline Conclusion & $\begin{array}{l}\text { Both Classes are } \\
\text { homogenous }\end{array}$ & $\begin{array}{l}\text { Both Classes are } \\
\text { homogenous }\end{array}$ \\
\hline
\end{tabular}

Based on normality and homogenity test show that neither pre-test nor post-test normally distributed. However, both pre-test and post-test have the same type. Therefore, hypothesis is calculated by using Mann-Whitney test. The MannWhitney test is shown in following Table 4.

Table 4. Hypothesis test result of pre-test and post-test of experimental and controlled class

\begin{tabular}{lll}
\hline Statistic & Pretest & Posttest \\
\hline Sig. (2-tailed) & 0,062 & 0,0000 \\
\hline $\begin{array}{l}\text { Significance } \\
\text { level }(\boldsymbol{\alpha})\end{array}$ & 0,05 & \\
\hline Conclusion & $\mathbf{H}_{\mathbf{0}}$ is accepted & $\mathbf{H}_{\mathrm{a}}$ is accepted \\
\hline
\end{tabular}

Based on Table 4 shows that hypothesis test of pre-test has significance score (2-tailed) $>0,05$. It means that null hypothesis is accepted and alternative hypothesis is rejected or in other word before being given treatment neither experimental nor controlled class has no any significant differences in creative thinking ability. Meanwhile, hypothesis result of post-test shows significance score (2-tailed) $<0,05$. It means null hypothesis is rejected and alternative hypothesis is accepted. In other word, there is significant increase on students' creative thinking ability after treatment between experimental and controlled class. It shows that there is significant effect of inquiry learning model with pictorial riddle technique towards students' creative thinking ability. The enhancement result of students' creative thinking ability (N-Gain) of experimental and controlled class can be seen in following Table 5 .

Based on Table 5 shows that after treatment either experimental or controlled class experiences enhancement on creative thinking ability. Moreover, experimental class experiences significant enhancements in each indicator in medium category. Meanwhile, in controlled class only one indicator experiences significant enhancement in medium category and other three indicators are in low category. The analysis of quessionaire is done in order to know students' responses to the application of inquiry learning model with pictorial riddle technique digital-based on experimental class. The result of the analysis can be seen in following Table 6 .

Table 5. Enhancement result of students' creative thinking ability of experimental and controlled class

\begin{tabular}{|c|c|c|c|c|c|c|c|c|c|}
\hline \multirow[t]{2}{*}{$\mathbf{N}$} & \multirow{2}{*}{$\begin{array}{l}\text { KB } \\
\text { Kr } \\
\text { Indi } \\
\text { cato } \\
\text { rs }\end{array}$} & \multicolumn{4}{|c|}{ Experimental Class } & \multicolumn{4}{|c|}{ Controlled Class } \\
\hline & & $\begin{array}{l}\text { Pr } \\
\text { ete } \\
\text { st }\end{array}$ & $\begin{array}{l}\text { Po } \\
\text { stt } \\
\text { est }\end{array}$ & $\begin{array}{l}- \\
\text { G } \\
\text { ai } \\
\text { n }\end{array}$ & $\begin{array}{l}\text { Cat } \\
\text { ego } \\
\text { ry }\end{array}$ & $\begin{array}{l}\text { Pr } \\
\text { ete } \\
\text { st }\end{array}$ & $\begin{array}{l}\text { Po } \\
\text { stt } \\
\text { est }\end{array}$ & $\begin{array}{l}\text { N } \\
- \\
\text { G } \\
\text { ai } \\
\text { n }\end{array}$ & $\begin{array}{l}\text { Cat } \\
\text { ego } \\
\text { ry }\end{array}$ \\
\hline 1 & $\begin{array}{l}\text { Flue } \\
\text { ncy }\end{array}$ & $\begin{array}{l}24, \\
58\end{array}$ & $\begin{array}{l}68, \\
75\end{array}$ & $\begin{array}{l}0, \\
5 \\
9\end{array}$ & $\begin{array}{l}\mathrm{Me} \\
\text { diu } \\
\mathrm{m}\end{array}$ & $\begin{array}{l}37, \\
08\end{array}$ & $\begin{array}{l}52, \\
50\end{array}$ & $\begin{array}{l}0, \\
2 \\
5\end{array}$ & $\begin{array}{l}\text { Lo } \\
W\end{array}$ \\
\hline 2 & $\begin{array}{l}\text { Flex } \\
\text { ibilit } \\
\text { y }\end{array}$ & $\begin{array}{l}30, \\
00\end{array}$ & $\begin{array}{l}71, \\
67\end{array}$ & $\begin{array}{l}0, \\
6 \\
0\end{array}$ & $\begin{array}{l}\mathrm{Me} \\
\text { diu } \\
\mathrm{m}\end{array}$ & $\begin{array}{l}37, \\
08\end{array}$ & $\begin{array}{l}65, \\
83\end{array}$ & $\begin{array}{l}0, \\
4 \\
6\end{array}$ & $\begin{array}{l}\mathrm{Me} \\
\text { diu } \\
\mathrm{m}\end{array}$ \\
\hline 3 & $\begin{array}{l}\text { Orig } \\
\text { inali } \\
\text { ty }\end{array}$ & $\begin{array}{l}23, \\
75\end{array}$ & $\begin{array}{l}52, \\
50\end{array}$ & $\begin{array}{l}0, \\
3 \\
8\end{array}$ & $\begin{array}{l}\mathrm{Me} \\
\text { diu } \\
\mathrm{m}\end{array}$ & $\begin{array}{l}23, \\
33\end{array}$ & $\begin{array}{l}42, \\
08\end{array}$ & $\begin{array}{l}0, \\
2 \\
4\end{array}$ & $\begin{array}{l}\text { Lo } \\
\text { W }\end{array}$ \\
\hline 4 & $\begin{array}{l}\text { Elab } \\
\text { orati } \\
\text { on }\end{array}$ & $\begin{array}{l}38, \\
33\end{array}$ & $\begin{array}{l}72, \\
33\end{array}$ & $\begin{array}{l}0 \\
5 \\
5\end{array}$ & $\begin{array}{l}\mathrm{Me} \\
\text { diu } \\
\mathrm{m}\end{array}$ & $\begin{array}{l}43, \\
67\end{array}$ & $\begin{array}{l}57, \\
33\end{array}$ & $\begin{array}{l}0, \\
2 \\
4\end{array}$ & $\begin{array}{l}\text { Lo } \\
W\end{array}$ \\
\hline
\end{tabular}

Table 6. Analysis result of students' responses to the application of inquiry learning model with pictorial riddle tehnique digital-based

\begin{tabular}{|c|c|c|c|}
\hline No & $\begin{array}{l}\text { Quessionaire } \\
\text { Indicators }\end{array}$ & Percentage & Category \\
\hline 1 & $\begin{array}{lr}\text { The application of } \\
\text { inquiry learning } \\
\text { model } \\
\text { pictorial with } \\
\text { technique digital- } \\
\text { based in learning } \\
\text { process }\end{array}$ & $82 \%$ & Very good \\
\hline 2 & $\begin{array}{lr}\text { The effect of } \\
\text { inquiry } & \text { learning } \\
\text { model } & \text { with } \\
\text { pictorial } & \text { riddle } \\
\text { technique } & \text { digital- } \\
\text { based on } & \text { students' } \\
\text { creative } & \text { thinking } \\
\text { ability } & \end{array}$ & $75 \%$ & Good \\
\hline \multicolumn{2}{|c|}{ Average } & $78 \%$ & Good \\
\hline
\end{tabular}

Based on Table 6 shows that students' responses to the application of inquiry learning 
model with pictorial riddle rechnique digital-based is in very good category. Meanwhile, students' responses to the effect of inquiry learning model with pictorial riddle technique digital-based is in good category. In conclusion, overall, the learning process by using inquiry learning model with pictorial riddle technique digital-based gains positive responses.

The analysis shows that, before the treatment, the mean score of experimental class is lower than controlled class. However, after the treatment, the mean of experimental class is higher than controlled class. It is showed based on hypothesis test that significant score (2tailed)<significant level $(\alpha)$. It means that there is an effect of inquiry learning model with pictorial riddle technique on students' creative thinking ability. According to Wardani et al. (2019), the implementation of inquiry learning model with pictorial riddle technique can affect students' creative thinking ability. Meanwhile, the N-Gain score of creative thinking ability of experimental class is higher than controlled class. This enhancement occurs in every indicator, they are fluency, flexibility, originality, and elaboration.

In the fluency indicator, experimental class is better than controlled class on formulating problems stage. This stage serves two different riddling phenomena that stimulate students to give their ideas. Stimulating students' curiosity can develop their creative thinking ability in fluency indicator (Putra et al., 2016). Furthermore, inquiry learning model with pictorial riddle technique digital-based also can enhance flexibility indicator because it trains students to discuss in formulating hypothesis. During formulating hypothesis, students are guided to find variative solutions to solve problems. According to Fitri \& Septifiana (2013), the height of flexibility indicator is marked by if students can observe a problem from some point of views while formulating hypothesis. Creative thinking ability of experimental class is higher than controlled class on originality indicator since students are served problems in illustration picture forms. It motivates students to find solutions they have never thought. It certainly stimulates students to train their thinking ability originally (originality) (Devi et al., 2019). The enhancement of originality is caused by there is a stage in which students are involved to do an investigation. During investigation, unimmediately, it encourages students to develop creative ideas in finding new knowledge by combining basic knowledge with new knowledge they just found during this stage (Sulastri et al., 2019). In elaboration indicator, experimental class is better than controlled class. It is caused by analyzing the investigation result stage and conclusing the result stage. These two stages, train students to solve problem gradually and detailed (Srifujiyati, Kamaluddin, 2018).

Overall, inquiry learning model with pictorial riddle technique digital-based be able to enhance students' creative thinking ability and get positive responses. It means inquiry learning model with pictorial riddle technique digital-based can be a learning model that gives positive effects to overcome the low of students' creative thinking ability especially in temperature and heat. However, the inquiry model using the digital-based pictorial riddle technique also has its drawbacks. This deficiency could be seen from the N-Gain results on the original thinking indicator (originality) which is lower than other indicators. Due to the investigation stage presented in the simulation has not been able to optimally generate the new ideas in solving problems. Therefore, the investigation stage should be presented in the form of a virtual practicum. The presentation is able to help the students in designing tools and materials, since that the students are able to explore in finding a new knowledge. The results of Mardhiyana \& Sejati (2016) research stated that the learning process using virtual practicum could generate the new ideas in solving.

\section{CONCLUSION}

The result of the study shows that there is an effect of inquiry learning model with pictorial riddle technique digital-based on students' creative thinking ability towards temperature and heat concept. It can be seen on the hypothesis test of post-test that significance score 2-tailed $(0,0000 \ldots)$ $<$ significance level (0.05). Moreover, the N-Gain 
result shows that experimental class experiences significant enhancement on creative thinking ability in medium category on all of indicators. Furthermore, the quessionaire result of students' interest on inquiry learning model with pictorial riddle technique digital-based gains good category (78\%).

\section{REFERENCES}

Devi, S. S., Munawaroh, F., Hadi, W. P., \& Muharrami, L. K. (2019). PEMBELAJARAN GUIDED INQUIRY DENGAN METODE PICTORIAL. Natural Science Education Research, 2, 40-47. https://journal.trunojoyo.ac.id/nser/article/vie w/4275

Fitri, S. G. ., \& Septifiana, V. (2013). Kreativitas Siswa dalam Pembuatan Model Struktur 3D Sel pada Pembelajaran Subkonsep Struktur dan Fungsi Sel. Prosiding Semirata FMIPA Universitas Lampung, 333-338. https://jurnal.fmipa.unila.ac.id/semirata/articl e/view/628

Guilford, J. . (1966). Measuremen and Creativity. Thepry into Practice, 5(4), 186-189. https://www.jstor.org/stable/1475131?seq=1

Khoiri, A., Sunarno, W., Sajidan, \& Sukarmin. (2019). Inquiry training model to improve creativity student in environmental physics courses. AIP Conference Proceedings, 2194(December).

https://doi.org/10.1063/1.5139781

Kristianingsih, D. D., Sukiswo, S. E., \& Khanafiyah, S. (2010). Peningkatan Hasil Belajar Siswa Melalui Model Pembelajaran Inkuiri Dengan Metode Pictorial Riddle Pada Pokok Bahasan Alat- Alat Optik Di Smp. Jurnal Pendidikan Fisika Indonesia, 6(1), $10-13$.

https://doi.org/10.15294/jpfi.v6i1.1095

Lestari, D. P., Sudarti, \& Supriadi, B. (2016). Pengembangan Modul Pembelajaran Fisika Kontekstual Berbasis Fisika Gasing (Gampang, Asyik, dan Menyenangkan) pada
Materi Suhu dan Kalor di SMA. Seminar Nasional Pendidikan 2016, 1, 96-107.

M. E. Winarno. (2013). Metodologi Penelitian dalam Pendidikan Jasmani (Cetakan ke). Universitas Negeri Malang UM Press.

Ma'rifah, E. (2016). Identifikasi Kesulitan Siswa Pada Materi Suhu Dan Kalor. Jurnal Pembelajaran Fisika Universitas Jember ISSN : 2527 - 5917, Vol.1, 4(5), 124-133. jurnal.unej.ac.id

Mardhiyana, D., \& Sejati, E. O. W. (2016). Mengembangkan Kemampuan Berpikir Kreatif dan Rasa Ingin Tahu Melalui Model Pembelajaran Berbasis Masalah. PRISMA, Prosiding Seminar Nasional Matematika, 672-688.

https://journal.unnes.ac.id/sju/index.php/pris ma/article/view/21686

Muhammad Fathurrohman. (2016). Model - model Pembelajaran Inovatif Alternatif Desain Pembelajaran yang Menyenangkan (Nur Hidayah (Ed.); II).

Muliyani, R., Kurniawan, Y., Studi, P., Fisika, P., Pascasarjana, S., \& Pendidikan, U. (2014). MELALUI MODEL PEMBELAJARAN KOOPERATIF TIPE Program Studi Pendidikan Fisika, Sekolah Pascasarjana Universitas Pendidikan. Prosiding Seminar Nasional Fisika Dan Pendidikan Fisika (SNFPF) Ke-5 2014, 5, 117-124. www.jurnal.fkip.uns.ac.id

Nilova, N. (2017). Pengaruh Metode Pembelajaran Inkuiri (Vol. 3, Issue 4) [UIN Raden Intan Lampung]. http://repository.radenintan.ac.id/id/eprint/30 54

Nurrahmah, F. (2015). PROFIL PROSES BERPIKIR KREATIF SISWA KELAS $X$ JENIS KELAMIN DAN PRESTASI BELAJAR FISIKA [UIN Walisongo]. http://eprints.walisongo.ac.id/id/eprint/4542

Putra, R. D., Rinanto, Y., Dwiastuti, S., \& Irfa, I. (2016). Peningkatan Kemampuan Berpikir Kreatif Siswa melalui Model Pembelajaran Inkuiri Terbimbing pada Siswa Kelas XI 
MIA 1 SMA Negeri Colomadu Karanganyar Tahun Pelajaran 2015 / 2016 The Increasing of Students Creative Thinking Ability Through of Inquiry Learni. Proceeding Biology Education Conference, 13(1), 330334. jurnal.fkip.uns.ac.id

Saputro, R. P., Wasis, W., \& Koestiari, T. (2017). PENGEMBANGAN PERANGKAT PEMBELAJARAN FISIKA MODEL DISCOVERY LEARNING UNTUK MENINGKATKAN HASIL BELAJAR DAN KETERAMPILAN BERPIKIR KREATIF. JPPS (Jurnal Penelitian Pendidikan Sains), 5(1), 693. https://doi.org/10.26740/jpps.v5n1.p693-702

Srifujiyati, Kamaluddin, dan M. P. (2018). Pengaruh Model Pembelajaran Inkuiri Terbimbing ( Guided Inquiry ) terhadap Keterampilan Berpikir Kreatif Siswa SMA Negeri 5 Palu. Jurnal Pendidikan Fisika Tadulako (JPFT), 6(1), 1-5.

Sugiyono. (2015). Metode Penelitian Kuantitatif, Kualitatif dan RnD. Alfabeta. www.cvalfabeta.com

Sulastri, F., Utami, L., \& Octarya, Z. (2019). F . Sulastri , Lisa Utami \& Z . Octarya PENGARUH PENERAPAN MODEL PEMBELAJARAN INKUIRI TERBIMBING ( GUIDED INQUIRY ) BERBANTUAN LEMBAR KERJA SISWA TERHADAP Keywords: Guided Inquiry Learning Model, Student Workbook Guided
Inquiry Based , Creative Thinking. Konfigurasi, $\quad 3, \quad 15-22$. https://doi.org/http://dx.doi.org/10.24014/ko nfigurasi.v3i1.6802

Sund, R. B., \& Trowbridge, L. W. (1967). Robert B. Sund, Leslie W. Trowbridge - Teaching science by inquiry in the secondary school Merrill (1973).pdf. Charles E. Merrill Publishing Company.

Tendrita, M., Mahanal, S., \& Zubaidah, S. (2016). Empowerment of Creative Thinking Skills through Think Pair Share Remap Model. Proceeding Biology Education Conference (ISSN: 2528-5742), 13(1), 285-291. https://jurnal.uns.ac.id/prosbi/article/view/57 22

Torrance, E. P. (1965). Scientific Views of Creativity and Factors Affecting Its Growth. Daedalus, 94(3), 663-681. http://www.jstor.org/stable/20026936

Wardani, A. R., Gummah, S., \& Ahzan, S. (2019). The Effect of Inquiry Learning Model with Pictorial Riddle Method on Students' Creative Thinking Ability. Lensa: Jurnal Kependidikan Fisika, 7(1), 19. https://doi.org/10.33394/j-lkf.v7i1.1905

Yuliani, H. (2017). Keterampilan Berpikir Kreatif Pada Siswa Sekolah Menengah Di Palangka Raya Menggunakan Pendekatan Saintifik. Jurnal Pendidikan Fisika Dan Keilmuan (JPFK), $\quad 3(1), \quad 48$. https://doi.org/10.25273/jpfk.v3i1.1134. 